\begin{tabular}{lcl}
\hline \multicolumn{1}{c}{ A N N A L E S } \\
UNiversitatis & MARIAE CURIE-SKŁODOWSKA \\
LUBLIN - POLONIA & 2019 \\
\hline
\end{tabular}

Institute of Political Science and International Relations of the Jagiellonian University

\title{
Poland and the Problem of Smog - Political Action Versus Social Expectations
}

\begin{abstract}
The aim of the article is to draw the European readers' attention to the problem that the citizens of Poland must face every year during the heating season - the danger of smog. The article is divided into several parts. The first one shows the scale of the problem - the enormous danger to human health posed by breathing bad quality air. The second part discusses the cause of the lack of serious action taken by the Polish government, namely the power of the mining lobby. The third part focuses on those aspects of contemporary reality that do not allow politicians to fully manipulate society (in the context of the smog problem). The fourth part contains a closer look at the grassroots social initiatives of the citizens; it describes the activities of Poles who try to counter smog. The last part includes the conclusions as well as some ideas on how to help Poles breathe better quality air.
\end{abstract}

Key words: smog, air pollution, Poland, Polish government

\section{INTRODUCTION}

Europeans live about 8 months shorter due to air pollution, Poles - 10 months shorter. The aim of the article is to illustrate the passivity of Polish authorities towards the problem of smog in Poland, to indicate the lack of prospects for improvement of air quality in Poland and to identify the tools that citizens have when fighting smog and to underline the passivity of the authorities. ${ }^{1}$

1 This issue is undertaken by such authors as Stefan Godzik, Stanisław Hławiczka, Piotr Poborski [1995], and Michał Kaczmarczyk [2015]. It is worth noting, however, that the problem is not studied in depth in Poland. The number of book-length publications on the subject is limited. 
The statistics on air quality in Poland are alarming, but it must be borne in mind that this also applies to the entire European Union. It is worth examining them more closely to see the scale of the problem we face in our country and throughout the European Union. Every year in Europe, half a million people die due to smog, in Poland -47 thousand. This data is related only to deaths themselves, but there are significantly more problems resulting from breathing bad quality air. They begin in foetal life - children are born smaller, their immune systems are weaker and they are more frequently affected by pulmonary diseases. Men have trouble with fertility, because smog contributes to lowering their testosterone levels. Bad quality air is conducive to the development of coronary heart disease. Smog is a particular threat to people who suffer from any type of heart disease. ${ }^{2}$ Smog increases overall mortality by $6 \%$, and cardiovascular deaths - by $8 \%$; additionally, it is the cause of heart attacks and strokes (the risk of heart attacks "increases at high concentrations of nitric oxide, nitrogen dioxide, suspended particulate matter and lower ozone levels, as well as lower atmospheric pressure values") [Zawat serca od smogu 2017].

Scientific research in recent years has produced results that determine what is a real threat to human health. Prof. Andrzej Lekston, MD, from the $3^{\text {rd }}$ Chair and Department of Clinical Cardiology of the Medical University of Silesia and the Silesian Center for Heart Diseases in Zabrze, tells us what is really dangerous:

The most harmful are the fine dust particles in the air. They are classified according to size. PM10 refers to particles smaller than 10 microns. PM2.5 and PM1.0 are respectively 2.5 and 0.1 microns. And that is what is called thoracic fraction (penetrating the chest cavity), respirable fraction (penetrating into the alveoli) and ultra-fine dust. In general, the smaller particles penetrate deeper into the lungs than the larger particles, so they have a longer-lasting effect. Fine dust with particles from 5 to 10 micron particles reaches only the nasopharynx, while 3 micron-sized particles reach as far as the bronchia [Zawat serca od smogu 2017].

How do we feel when air pollution exceeds acceptable standards? We are tired, sleepy, we feel fatigued, we may experience chest pain, coughing or difficulty breathing, as well as instability and jumps in blood pressure. Naturally, poor well-being or symptoms of illness make the number of visits to general practitioners increases with poor air quality. Not everyone is aware that even when the smog is gone, the effects remain for up to two weeks. It would therefore be rational from an economic point of view to remove the cause of significant expenditures in the Polish social insurance system every year, but that is not the case. Below, we will try to find out why there are no serious changes in order to remedy this situation.

2 Statistical data and this information taken from: Zawat serca od smogu [2017], https://silesion.pl/ zawal-serca-od-smogu-03-02-2017 (access: 1.03.2017). 


\section{WHY DOES THE POLISH GOVERNMENT NOT MAKE A REAL EFFORT} TO FIGHT SMOG?

There are several causes for the lack of serious systematic solutions undertaken by the Polish authorities. The most important and most difficult to change, which must be discussed, is the fact that the Polish economy is based on coal. In the West, the civilisation of coal and steel ended approximately in the 1960s [Wilkoszewska 2000] and was associated with the creation of the post-industrial society. ${ }^{3}$ At that time, there was a period in the history of Western culture, in which the tradition of the domination of coal and steel began to be replaced by information civilisation; "dirty" industries were replaced by "clean" industry", wealth was generated by the implementation of new technologies; intellectual work appeared in place of hard physical labour; industrial production was supplanted by the sphere of services. ${ }^{4}$ Our economic transformation in the context of departure from a coal-based economy is taking place very slowly. Poland lacks the government that would dare to make such a politically unpopular decision and enter into a conflict with the mining community. This kind of thinking is not rational from a political point of view, however, because the political authorities, favouring one social group (in this case, related to the mining industry), are discouraging voters throughout Poland, not just in the areas related to this industry. So, from a political point of view, it would be more profitable to please the whole nation rather than just one of its groups.

So why does the government not calculate its popularity? Primarily because the miners can, like no other professional group, fight for their rights and do so in an unconventional way. Their operating strategy resembles Lenin's tactics, contemporaneously described by Slavoj Žižek. The author of the afterword to Revolution at the Gates noted that the situation before the October Revolution in Russia resembles the position in which all social movements without representation in the system find themselves today. What can we learn - according to Žižek - from Lenin? First of all, break out of the political game set by the parliamentary order. Make demands "from the outside", forcing the representatives of the system to give up on existing rules. So, similarly to Lenin, who dealt with the Russian parliament in such a way that he created an extra-parliamentary party from the working peasant masses. What are the options available to Polish miners? Either act according to the rules of the system and walk the long road through the institutions, or break away from the rules and be heard. Miners in Poland act according to the second option, which is contrary to the rules of democratic order, not accepting the liberal-democratic consensus, not following the principles adopted in a liberal democracy [see: Žižek 2011]. Apart from burning tires in front of the Sejm, blocking roads and detaining the debating members

\footnotetext{
3 A post-industrial society is referred to as a service society. This concept emerged in the 1960 s and 1970s, and was described by, among others, Daniel Bell [1973] and Alain Touraine [1971].

4 Among the authors writing broadly about these phenomena was Zygmunt Bauman [2000].
} 
of parliament, they even resorted to threatening the MPs. Piotr Duda, the chairman of the Independent Self-governing Labour Union "Solidarity" clearly said in January 2015: "Nobody wants to listen to us, because people only talk to us when we want to strike or punch someone in the face" [Duda grozi posłom ze Ślaska. ... 2015].

Thus, the dialogue takes place only when they use measures not accepted under the existing order. He further threatened the Silesian MPs not to support a government bill that would shut down four mines: "We know your names, we know where you live, and immunity will not help you" [Duda grozi posłom ze Śląska: ... 2015].

Currently, the Polish government supports mining in various ways - certainly through enormous financial grants, but also in a more veiled manner, such as the passing of the controversial law on investments in wind power plants in May 2016. According to the opponents of the law, it contributes to a complete stop in the development of wind power in Poland [Sejm uchwalił kontrowersyjna ustawe... 2016].

The law means an increase in wind farm fees (an important hindering change is also the clause on distance from residential buildings), which is why there have already been eight lawsuits from companies related to the windmill industry. Prime Minister Beata Szydło appointed a special plenipotentiary to deal with these complaints. The opposition does not shy away from speaking openly about the matter - for example, MP Michał Stasiński of the Nowoczesna party: "Polish coal stands behind this law. Your energy mix is coal first, coal second, and coal third" [Sejm uchwalit kontrowersyjna ustawę... 2016].

It was mentioned above that in the era of post-modernism, we are dealing with the domination of wealth generated by, inter alia, new technologies. Let us note that energy from windmills is an example of this. However, in Poland, there is a reverse movement. We are going back to the times when the economy was based on coal, steel and the so-called "dirty" industry.

\section{CONTEMPORARY MANIPULATION OF POLISH PUBLIC OPINION}

In the age of the information civilisation and globalisation, it is difficult for governmental authorities to conceal certain information or to manipulate public opinion. Members of the information society in which we live have the ability to immediately verify information received from the authorities. Additionally, they have access to immense knowledge, which they can assimilate if they want to acquaint themselves with a given subject, which also undermines their susceptibility to accept banal messages. The modern citizen also has the ability to quickly organise a community which, integrated around a specific issue, is able to begin work on achieving set goals or tasks. Citizen can dynamically designate the location and type of meetings, or protest in several places at once against, for example, certain proposed legislative changes. An excellent example of this were the nationwide protests against the signing of ACTA by Poland. Demonstrations by opponents of the agreement to 
combat Internet piracy and counterfeit trade highlighted the mobility and readiness of contemporary citizens to protest on issues that directly concern them. This is an aspect that is directly linked to the subject of smog. The issue of air quality concerns society to a much greater degree and more directly than ACTA. The government should draw conclusions from the events that took place and try not to act against the interest of citizens and without an adequate information policy towards the public. Otherwise, the government's approval ratings will drop.

The capabilities of modern humanity are far greater than in pre-digitisation societies. This is why a new face of civil society is emerging [Ulikowska 2015]. That is why every state authority, regardless of the political option, must remember that public opinion is shaped for one's own purpose, informing it in general about the direction of planned changes (excessive, specialised knowledge is not necessary for the average citizen). Society must understand the basic goals and overall policies of its government, thus the need to shape public opinion, but not giving in to it. It is also worth noting that one of the manifestations of civil society is sustained and sustainable development. This concept is based on the idea that at the present level of civilisation, the possible development is the one in which the needs of the current generation can be met without reducing the chances of future generations meeting theirs. ${ }^{5}$

A "liquid modernity" - speaking in Bauman's language - also creates other situations. In the age of the Internet, it is difficult for government officials to retract opinions expressed, statements made or changes proposed. All declarations of government representatives (although this issue applies to all citizens) have their "second" life in the media space. This is a tool that, in political marketing, can simultaneously contribute to increased support but it can also be the cause of political disaster. The very provocative statement of the minister of health in Beata Szydło's cabinet, Konstanty Radziwiłł, is an excellent example of this - in January 2017, he declared smog to be a "theoretical" threat. Given that Poles live 10 months shorter due to air pollution, and that out of fifty cities in the European Union with the worst air quality, thirty are located in Poland, and - paradoxically - fourteen of them in Silesia, ${ }^{6}$ where coal is mined. In Silesia and Lesser Poland, the non-smoking Pole "smokes" seven cigarettes per day on average - and that is what Minister Radziwiłl considers to be a "slightly more theoretical" threat. He also suggested that our lifestyle is more dangerous - meaning smoking. But how can this theory be applied to non-smokers or children? Depressingly, the minister should not underestimate the

5 See the 1987 Report of the World Commission on Environment and Development, "Our Common Future", the so-called Brundtland Report, after the Commission's chairwoman, Gro Harlem Brundtland.

6 The term "paradoxically" refers to the fact that, if not for the mining lobby inhabiting these areas, a change in the energy policy of Poland would most likely occur more quickly. The pollution of these cities also unequivocally shows the scale of the problem of firing furnaces with bad quality coal, which only confirms the hypothesis of falsifying the smog problem, linking it only to the problem of car exhaust emissions. 
problem of smog, but the opposite - raise an alarm to combat it. That is why his statement aroused so much controversy.

The most common manipulation is the suggestion that cars are responsible for smog in Polish cities. That is why there are growing areas without vehicular traffic and free public transit travel is organised. However, a fundamental question arises: why is there no smog in the summer? Cars also drive in the streets in the summer, after all. The answer is obvious - because we do not use furnaces. As studies show, $80 \%$ of air pollution comes from private homes. Industry and cars are responsible for only $20 \%$ of it. What tasks should Polish political decision-makers face, then? Taking care of solving the problem of air pollution, coming largely from private households - why does no one take up this task? Because most of them use poor quality coal or refuse as furnace fuel, which means the government would have to risk the wrath of the mining industry. And thus, we come full circle.

The Internet is a very important area that politicians cannot trivialise. Virtual reality is linked to, among others, the problem of online harassment or the meme phenomenon. General access to information makes it difficult for the government to manipulate citizens. Currently, everyone has the ability to access air quality data and ways to measure pollution. What is alarming in Poland is the purposeful lowering of norms adopted in Europe and in the world. Fortunately, they can be verified. A comparison of data from Poland with recommendations from the World Health Organisation (WHO) shows the scale of falsification of the problem of smog in Poland. The WHO allows daily dust particle concentrations of $50 \mu \mathrm{g} / \mathrm{m}^{3}$ for PM10, while in Poland, the norm is $200 \mu \mathrm{g} / \mathrm{m}^{3}$ - a frightening comparison. In Paris, a smog alarm is activated at concentrations of $80 \mu \mathrm{g} / \mathrm{m}^{3}$, while in Poland, the number is 300 $\mu \mathrm{g} / \mathrm{m}^{3}$ for PM10. It is worth noting that until 2012, the alarm level was $200 \mu \mathrm{g} / \mathrm{m}^{3}$ (adopted in 2008). However, a regulation was adopted that year that relaxed the criteria for informing citizens about poor air quality. This decision is synonymous with reducing the protection of citizens from high levels of air pollution and demonstrates the downplaying of this problem. The conclusion is that we have the worst air in the EU, and we are most poorly informed about it. ${ }^{7}$

\section{CITIZEN AND LOCAL GOVERNMENT ACTIONS IN THE FIGHT AGAINST SMOG}

As mentioned above, one of the manifestations of civil society is sustained and sustainable development. There are, however, other important manifestations, which are worth pausing to examine in the context of this topic. Among them are social activity, non-governmental organisations and cooperation for the good of the

\footnotetext{
7 A clear overview of the level of information and alerting can be found at: Polski Alarm Smogowy, http://www.polskialarmsmogowy.pl/polski-alarm-smogowy/smog/szczegoly,poziomy-informowania-ialarmowe, 19.html (access: 09.04.2017).
} 
community. From the point of view of the objectives of the deliberations, several manifestations of grassroots activism are worthy of analysis.

The Polish Smog Alarm (Polski Alarm Smogowy) is a particularly important initiative. The essence of this initiative lies in the association's slogan - "together for clean air". From the perspective of civil society, the community character of this undertaking is important. The idea of the Alarm covers all Poland, since it includes local smog alarms, in such regions as Silesia or Lesser Poland. Thanks to these alarms, information from particular areas of Poland is shared. The Polish Smog Alarm website includes valuable information about the smog map in Poland [Polski Alarm Smogowy]. The foundation also shares the newest publications on the subject, and recently the book Wpływ zanieczyszczen powietrza na zdrowie [2017] was recommended. The book was written by a team of specialists from a variety of disciplines - physical chemistry, cardiology, environmental protection and allergology. It explains the scale of the destructive influence of smog on people's functioning in an accessible way. The website also includes comparisons of data from the European Union and Poland on air pollution standards and scale.

Another manifestation of the commitment to the good of the community is, for example, the daily air quality news service on Radio TOK FM. This information meets the needs of the audience. It is worth pointing out that the service uses the standards of the WHO, and not the lowered Polish standards. On the radio, in addition to information, listeners can also hear definitions of the basic concepts of air quality control. This is an excellent idea, because it gives Poles increasingly better knowledge about smog and related problems.

It is also worth pointing out another type of citizen involvement in the fight against smog. There are initiatives of homeowner associations purchasing information boards about the level of air pollution. In Kraków, where the smog level during the heating season is extremely high, such boards are placed at public transportation stops, which facilitates access to data for all inhabitants.

The activity that brings the most hope is the work of local governments. It may be put simply thus: since the government is not doing anything, local governments do it instead. It would be difficult for miners to start fighting individual local governments that begin work on improving air quality and replacing coal furnaces with others. One of the latest local government initiatives of this type was the subsidising of furnace replacements in Radom. The interest in furnace replacement exceeded the expectations of the local government, which had to increase the amount of funds allocated for this purpose [Radom doptaci mieszkańcom do wymiany pieców... 2017].

It is encouraging that so many people wanted to take advantage of this offer and queued up at city offices to fill in the required documents. This shows a change in the awareness of Poles as to the standards of thinking about the problem of smog. At the same time, it is impossible, however, not to regret the top-down decisions, which are not favourable for local governments. An example of this is not granting of a non-refundable grant of PLN 20 million to Kraków for the fight against smog - 
an amount that was needed to receive a PLN 42 million subsidy from the European Union. At the same meeting of the National Fund for Environmental Protection and Water Management, an agreement was reached with Father Tadeusz Rydzyk's Lux Veritatis Foundation, which received PLN 26 million (plus interest).

\section{CONCLUSIONS}

As the data on the health of citizens clearly shows, the number of illnesses, and the frequency of using doctor's services that follows, are growing. From the perspective of the health insurance system, it would be best to remove the causes of more frequent illnesses rather than spending huge sums of money just on eliminating the effects of smog. A logical solution, which is the responsibility of the Polish authorities, is the elimination of smog, and the consequent improvement of citizens' health. If we take care of the air quality in Poland, the number of illnesses and complications will be reduced, leading de facto to saving a lot of money for the state health care system. It is therefore worth taking on long-term, effective solutions that have an impact on reality, rather than ad hoc, pseudo actions. Recently (May 2017), the Marshal's Office of the Masovian Voivodeship presented the "Air Protection Programme" for public consultations. Non-governmental organisations have not found any specific solutions to the smog problem in the 1,200 pages, only generalities and pious wishes. This fact illustrates the policy-makers' approach to the problem of smog. It clearly shows that no major changes to environmental policy are planned, especially those with particular emphasis on improving air quality. ${ }^{8}$

The absence of action by the government can also be seen in the policy of the Ministry of Energy, which does not want coal quality certificates. This subject is related to the above-mentioned problem of reluctance to confront the community connected with Polish mining. In this way, the persistent ignoring of a blind spot is made clear - if a dialogue is not established and realistic steps are not taken towards changing the Polish coal policy, we cannot improve the quality of the air Poles breathe.

Nowadays, coal consumers know practically nothing about the coal for which they pay - not how sulphurous it is, how moist it is, or even what its caloric content is. (...) "The current law allows for pulling the wool over Kowalski's eyes. You can sell him anything you want. For example, wet coal is often used in furnaces, and burning it causes not only high dust emissions, but also puts a financial burden on the buyer because the evaporation of water - which does not burn, after all - consumes a significant part of

\footnotetext{
${ }^{8}$ It may even be concluded that the government is hindering the fight against smog by introducing Minister Jan Szyszko's law that allows for uncontrolled deforestation. There is no need to tell anyone about the role trees play in improving air quality.
} 
the energy", comments Andrzej Guła from the Polish Smog Alarm. At the same time, he notes that the lack of certificates is a problem not only for customers who buy coal, but also for all of us, because poor-quality fuel will be used in the furnaces and the resulting emissions will contribute to the smog problem [Wegiel, czyli co? 2017].

Let us move on to details. What realistic tasks could the government undertake that would improve the air quality in our country? First, introduce mandatory certification and quality control of the coal sold (as in the case of gasoline, where we know exactly what we put in our tanks). Second, prohibit the fitting of waste-fired furnaces in new homes (which burn every kind of waste). Third, organise the replacement of already-installed waste-fired furnaces to environmentally- and financially-friendly furnaces. Fourth, subsidize or finance the replacement of furnaces. ${ }^{9}$ Further suggestions for solutions can be added: control - after the Czech model - of the fuel used (in the Czech Republic, officials have the right to enter homes every two years and check what is being used to heat it); the inevitability for penalties for polluting the air (it is not the amount of penalties that matters, but the inevitable fact that they cannot be avoided); co-financing better-quality furnace fuel for the poor. Examples of smog-combatting policies in the European Union show that they bring real results, namely better air.

What kind of positive aspects can be found in this difficult situation of a lack of state support? The awareness of citizens about the threat of smog is hopeful, raised by activists and educators. Additionally, supporting the fight against smog is the work of local governments, which have declared a grassroots war on poor air quality.

International conferences on ecology, security or climate allow the internationalisation of a seemingly local-only problem, because air, along with other resources, such as water, is a supranational commodity. On the other hand, belonging to the European Union gives Polish citizens a sense that even if our authorities do not take appropriate steps to fight smog, then seeing the case of the decisions regarding Bulgaria, the European Union will take up the fight against smog in Poland.

Finally, it is worth nothing the actions of the European Union in the aforementioned case of Bulgaria and consider whether it is a warning for Poland. In April 2017, the Court of Justice of the European Union issued a judgement in the case of violation of a directive on ambient air quality (CAFE). The defendant was found guilty for failing to fulfil obligations under the provisions of the directive on ambient air quality and did not present the appropriate reparative measures. It should also be noted that similar allegations have been made against Poland.

In conclusion, it should be argued that political actions must finally respond to social expectations. The problem of smog concerns the masses, which cannot be

\footnotetext{
9 As a model, we can look at the policy in the United Kingdom following the problem of the great smog in 1952, which was successfully resolved by adopting the Clean Air Act 1956, thereby improving living conditions in London and reducing harmful emissions throughout the country.
} 
ignored in the long run. The interests of one industry group (even as numerous as the miners in Poland) cannot be put above the needs of an entire society.

\section{BIBLIOGRAPHY}

Bauman, Z. 2000. Liquid Modernity, Polity, Cambridge.

Bell, D. 1973. The Coming of Post-Industrial Society: A Venture in Social Forecasting, Basic Books, New York.

Duda grozi posłom ze Śląska: wiemy, gdzie mieszkacie. „Mamy się bać o zdrowie, o życie?”. 2015, http:// www.tvn24.pl/wiadomosci-z-kraju,3/piotr-duda-grozi-poslom-ze-slaska-wiemy-gdzie-mieszkacie,505839.html (access: 9.03.2017).

Godzik, S., Hławiczka, S., Poborski, P. (eds.) 1995. Smog: przyczyny -skutki-przeciwdziałania, Państwowa Inspekcja Ochrony Środowiska, Warszawa.

Jędrak, J., Konduracka, E., Badyda, A.J., Dąbrowiecki, P. 2017. Wplyw zanieczyszczeń powietrza na zdrowie, http://www.krakowskialarmsmogowy.pl/files/images/ck/14882713101616070935.pdf (access: 3.05 .2017$)$.

Kaczmarczyk, M. (ed.) 2015. Niska emisja: od przyczyn występowania do sposobów eliminacji, Geosystem Burek, Kotyza s.c., Kraków.

Polski Alarm Smogowy, http://www.polskialarmsmogowy.pl/polski-alarm-smogowy/smog/ szczegoly,poziomy-informowania-i-alarmowe,19.html (access: 9.04.2017).

Radom dopłaci mieszkańcom do wymiany pieców. Pięć tysięcy złotych dla gospodarstwa domowego. 2017, https://echodnia.eu/radomskie/radom-doplaci-mieszkancom-do-wymiany-piecow-piec-tysiecyzlotych-dla-gospodarstwa-domowego/ar/c3-11901676 (access: 3.05.2017).

Sejm uchwalit kontrowersyjna ustawę. "PiS wygrat z wiatrakami". 2016, https://tvn24bis.pl/z-kraju,74/ sejm-uchwalil-ustawe-wiatrakowa,645620.html (access: 02.04.2017).

Touraine, A. 1971. The Post-Industrial Society: Tomorrow's Social History: Classes, Conflicts and Culture in the Programmed Society, Random House, New York.

Ulikowska, D. 2015. Społeczeństwo obywatelskie, Polska Fundacja Ośrodków Wspomagania Rozwoju Gospodarczego „OIC Poland”, Lublin.

Węgiel, czyli co? - Ministerstwo Energii nie chce świadectw jakości węgla. 2017, http://www.polskialarmsmogowy.pl/polski-alarm-smogowy/aktualnosci/szczegoly,wegiel-czyli-co---ministerstwo-energii-niechce-swiadectw-jakosci-wegla,430.html (access: 30.04.2017).

Wilkoszewska, K. 2000. Wariacje na postmodernizm, Wydawnictwo Universitas, Kraków.

Zawat serca od smogu. 2017, https://silesion.pl/zawal-serca-od-smogu-03-02-2017 (access: 1.03.2017).

Žižek, S. 2011. Revolution at the Gates: Selected Writings of Lenin from 1917, Penguin Random House, New York.

\section{BIOGRAPHY}

Anna Citkowska-Kimla, dr hab., prof. UJ. She graduated from the Jagiellonian University with a degree in political science, Polish philology and philosophy. She works at the Institute of Political Science and International Relations of the Jagiellonian University, in the Chair of Contemporary Political Doctrines. Guest lecturer at the University of Vienna; Goethe scholarship holder at the Friedrich-Schiller 
University of Jena. She has been a guest at the following universities: Paris Lodron University of Salzburg, Eötvös Loránd University in Budapest, Ruprecht Karl University of Heidelberg, University of Padua, Free University of Berlin. Winner of the Rector's Scholarship and the Rector's Magnificence Award of the Jagiellonian University. She is a member of the record-keeping corpus of such institutions as "Studies on Authoritarianism and Totalitarianism", "Annales", "Wrocław Erazmanian Studies", "Politics and Security", "Politea" and "Poliarchy". Member of the Polish Society of Political Sciences, member of the Board of the Polish Society of Political Thought, member of the European Consortium for Political Research, member of the Central European Political Science Association. She deals with the history of political thought, especially German thought, as well as with contemporary political doctrines and movements. She studies the paradigm of Romanticism in politics. Author of books, editor of scientific papers, chapters printed in collective papers and scientific articles in Polish and foreign magazines. Selected publications: Romantyzm polityczny w Niemczech. Reprezentanci, idee, model (Kraków 2010); Politische Ideen deutschsprächiger Denker im. 20. Jahrhundert. Von Karl Jaspers bis Golo Mann (Kraków 2018); Paradigm of Political Romanticism (Sofia 2016); The History of Polish Environmental Protection Movements (Kraków 2016). E-mail: anna.citkowska-kimla@uj.edu.pl 